\title{
Merkel Cell Carcinoma pN1 TNM Finding v8
}

National Cancer Institute

\section{Source}

National Cancer Institute. Merkel Cell Carcinoma pN1 TNM Finding v8. NCI Thesaurus. Code C136863.

Merkel cell carcinoma with metastasis in regional lymph node(s). (from AJCC 8th Ed.) 